ZOOLOGIA 30 (3): 255-265, June, 2013

http://dx.doi.org/10.1590/S1984-46702013000300002

\title{
Diet and reproductive dynamics of Trachelyopterus lucenai (Siluriformes: Auchenipteridae) in subtropical coastal lagoons in southern Brazil
}

\author{
Renata Maia ${ }^{1,3}$, Luiz G. S. Artioli \& Sandra M. Hartz \\ ${ }^{1}$ Laboratório de Ictiologia, Departamento de Zoologia, Programa de Pós-graduação em Biologia Animal, Universidade \\ Federal do Rio Grande do Sul. Avenida Bento Gonçalves 9500, Setor 4, Prédio 43435, 91501-970 Porto Alegre, RS, Brazil. \\ ${ }^{2}$ Departamento de Ecologia, Universidade Federal do Rio Grande do Sul. Avenida Bento Gonçalves 9500, Setor 4, Prédio \\ 43422, 91501-970 Porto Alegre, RS, Brazil. \\ ${ }^{3}$ Corresponding autor. E-mail: renata.maia@ufrgs.br
}

\begin{abstract}
This study analyzed the diet and reproductive dynamics of Trachelyopterus lucenai Bertoletti, Pezzi da Silva \& Pereira, 1995, an allochthonous fish species in the subtropical coastal lagoons of the Tramandaí River, Rio Grande do Sul, Brazil. The fecundity of the species is described for the first time. Specimens were captured in the interconnected lagoons Itapeva, Quadros and Malvas, on a monthly basis, from November 2008 to April 2010, with gillnets of different mesh sizes. The food items identified were assessed for abundance and frequency of occurrence. The sex ratio, reproductive period for males and females, for mature females, fecundity, were estimated. These results were analyzed with respect to seasonal variation. We captured 135 individuals, including 82 females and 53 males, especially in months with high temperatures (October 2009 to March 2010). Females were more abundant than males in all months. There was no difference between the mean size of females and males, and both sexes showed allometric growth. The feeding analysis showed a generalist-opportunist food habit; 26 items were consumed, with a predominance of autochthonous items (insects and fish). Temporal variations in diet were associated with variations in water and air temperature and rainfall in the region, but these variations did not differ between males and females. The sex ratio differed significantly from 1:1, with 1.5 females per male. The reproductive period occurred from October to March, with most activity in November and December, and showing no variation between the peaks of gonadal development of males and females. The mean fecundity of mature females was 1,536 oocytes per spawning $(n=17)$. The feeding habits and reproductive behavior of the species in the study site are similar to those described for where the species is native. Although clearly seasonal, the reproductive period was long, in spite of the low fecundity. These features facilitate the establishment of $T$. lucenai and make it a good competitor in the new environment.
\end{abstract}

KEY WORDS. Allochthonous species; fecundity; opportunist-generalist.

Trachelyopterus (Valenciennes, 1840) contains 13 species and is widely distributed from Panama to rivers of the Brazilian coastal systems, through the Guianas, the Amazon basin and the Plate River (Ferraris JR 2007). Trachelyopterus lucenai Bertoletti, Pezzi da Silva \& Pereira, 1995, popularly known as "penharol" or "catfish-frog", is recorded from the Uruguay River and the Laguna dos Patos basins, both located in southern Brazil. According to local fishermen, the species has been found in the Laguna dos Patos Basin since 1989 (BERTOLETTI et al. 1992). Since then, it has been recorded in samples from different water bodies of the Laguna dos Patos system, such as Lake Casamento and Lake Gateados in the northeastern part of the system (Becker et al. 2007, Milani \& Fontoura 2007), ponds at the Estação Ecológica do Taim (Garcia et al. 2006b), and Lake Mangueira in the South (ARTioli et al. 2009).

In the Tramandaí River system (TRS), the species was first recorded from the Fortaleza Lagoon (Schifino et al. 2004) and is currently widespread in other lakes of the system (ARTIOLI \& MAIA 2010). Being a native species in other basins of Rio Grande do Sul (RS), it is classified as allochthonous to the TRS (EspINOLA \& JÚLIO JR 2007). It is widely distributed through the RS coastal basins and its dispersal has been linked to several factors, such as the geomorphological conditions of the coastal plain, human interference (BERTOLETTI et al. 1992), intrinsic biological characteristics (BurNs et al. 2002), and the presence of favorable habitats (GARCIA et al. 2006b).

Trachelyopterus lucenai has similar habits to species in other genera of Auchenipteridae, being more active at night, and hiding in the vegetation during the day (ANDrian et al. 1994, Moresco \& Bemvenuti 2005, Saccol-Pereira \& Fialho 2010). The feeding habits of the species were evaluated in the Guaíba Lake (BECKER 1998) and in ponds of the Estação Ecológica do Taim (Moresco \& BemVenuti 2005), and according to the results of those studies, the species is considered generalist-opportunist. 
The reproductive aspects of T. lucenai were studied in the Guaiba Lake (Becker 2001, Marques et al. 2007), as well as in the Gateados and Casamento Lakes (Milani \& Fontoura 2007), all of which belong to the Laguna dos Patos system. Males can be identified by the presence of two testicles formed by spermatic lobes, a vesicle, and a gelatinous sperm duct located in the abdominal cavity. They also possess a gonopodium, which is a modification of the first anal fin rays. This structure transfers the sperm to the female, increasing reproductive efficiency. The female has two elongated ovaries, situated on each side of the abdominal cavity, which are united only by the oviduct, where sperm is stored, showing no externally differentiated structure. Soon after ejaculation, the gelatinous substance (produced by the male) acts as a "buffer", closing the urogenital opening of the female, which only ruptures at the time of spawning (DE Pinna 1998, Araújo et al. 2000, Meisner et al. 2000, Reno et al. 2000, Burns et al. 2002).

Studies on the basic biology of fish are important for species management, and may help predict the species' behavior in other ecosystems. Although such studies have been conducted in aquatic ecosystems of the RS, they were restricted to native species. Allochthonous species generally have a high potential to become established in the community (AgostinHo et al. 2005), and may or not have deleterious effects on the native species. This study aimed to contribute to the basic knowledge of aspects of the biology of $T$. lucenai, describing the diet, sex ratio and reproductive period in subtropical coastal lagoons in southern Brazil. The fecundity is described for the first time. Our hypothesis is that the feeding habits of T. lucenai in the study site are the same as in other ponds, and a seasonal reproductive strategy (sensu WinemiLLer 1989) with intermediate fecundity, small ovocites and a short breeding season was expected.

\section{MATERIAL AND METHODS}

Samples were collected from the Itapeva, Quadros and Malvas lagoons belonging to the TRS $\left(29^{\circ} 45^{\prime}, 30^{\circ} 15^{\prime} \mathrm{S}\right)$, situated on the northern coastal plain of Rio Grande do Sul, which has an extension of about $640 \mathrm{~km}$ (SCHWARZBOLd \& SCHÄFER 1984). These coastal lagoons originated in the last 5,000 years through processes of marine transgressions and regressions, along with wind action. The climate, according to Köppen, is Cfa or subtropical humid (Hasenack \& Ferraro 1989). Wind action, mainly from the northeastern quadrant, is important because it determines the morphology and the hydrodynamics of these lagoons (Schwarzbold \& SchäFer 1984).

The lagoons are connected by naturals canals (about 15 $\mathrm{km})$, and have predominantly sandy bottoms and shores intensely colonized by emergent macrophytes. In the surroundings there are areas with rice fields that are seasonally flooded. The Quadros $\left(119 \mathrm{~km}^{2}\right)$ and Itapeva $\left(95 \mathrm{~km}^{2}\right)$ lagoons are part of the Municipality of Terra de Areia $\left(29^{\circ} 36^{\prime} \mathrm{S}, 49^{\circ} 58^{\prime} \mathrm{W} ; 2^{\circ} 45^{\prime} \mathrm{S}\right.$, $50^{\circ} 5^{\prime} \mathrm{W}$, respectively), and the Malvas Lagoon $\left(55 \mathrm{~km}^{2}\right)$ lies within the Municipality of Capão da Canoa $\left(29^{\circ} 47^{\prime} \mathrm{S}, 50^{\circ} 6^{\prime} \mathrm{W}\right)$. All those lagoons are shallow, less than $5 \mathrm{~m}$ deep (SCHÄFER 1988) (Fig. 1).

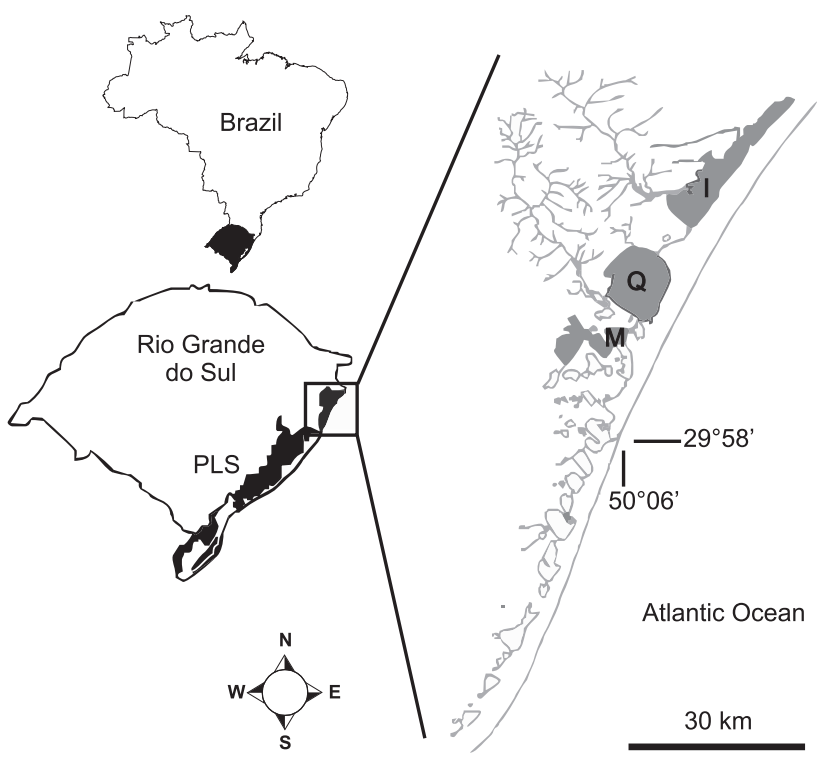

Figure 1. Map showing the location of the Tramandaí River system (black); Patos Lagoon system (PLS) (grey) and the coastal lagoons sampled: Itapeva (I), Quadros (Q) and Malvas (M) in the state of Rio Grande do Sul, Brazil.

Specimens were collected monthly from November 2008 to April 2010. We used sets of $30 \mathrm{~m}$ gillnets with several mesh sizes $(15,20,25,30,35,40,50,60$, and $70 \mathrm{~mm}$ between adjacent nodes), totaling $270 \mathrm{~m}$, placed in each lagoon. The gill nets were placed during the mid day, near the vegetation, at depths of 1-2 m, and were removed the next morning, remaining 18 hours/month on site, on average. The water temperature $\left({ }^{\circ} \mathrm{C}\right)$ was measured at the time of sampling, and the monthly means of air temperature $\left({ }^{\circ} \mathrm{C}\right)$ and rainfall $(\mathrm{mm})$ were obtained from the Fundação Estadual de Pesquisa Agropecuária (FEPAGRO). Representative specimens were deposited in the fish collection of the Zoology Department of the Universidade Federal do Rio Grande do Sul (UFRGS 11900, 11901, 11902).

The total length (TL) and total weight (TW) of each specimen were measured. The fish were dissected to remove the stomach and the gonads, which were weighed, and the intestines were measured $(\mathrm{mm})$. In the size analysis, classes with $30 \mathrm{~mm}$ intervals were used. For the temporal analysis, data were grouped bimonthly, combining the different years in the feeding analysis. Because of the connectivity of the lagoons and the small numbers of individuals examined, data from the different sampling points were combined and analyzed together, since we assumed that we were dealing with a single population. 
We analyzed the absolute abundance of females and males by month of collection and size class. Mean TLs of both sexes were compared by $t$ test $(\alpha=0.05)$. We evaluated the length-weight relationship of the specimens (VAzzoler 1996).

The fullness of the stomachs was assessed according to the amount of food found: I (empty), II (partially full) and III (full). The intestinal quotient (IQ) was determined from the mathematical expression: IQ = IL/TL (ZaVALA-CAMIN 1996), where $\mathrm{IL}=$ intestine length .

The food items were identified to the lowest taxonomic level possible, with the aid of a stereomicroscope and appropriate references (McCafferty 1981, Mugnai et al. 2010). Analyses were based on qualitative and quantitative methods according to the frequency of occurrence (FO) and percent abundance (PA). The FO is the ratio between the number of stomachs in which the item occurs, divided by the total number of stomachs; and the PA is the ratio between the sum of the number of individuals of each item, divided by the total number of individuals of all items (HysLop 1980). Using a combination of FO and PA, the items were rated on the following scale of relative importance (RI): 4 - abundant and frequent, 3 abundant, 2 - frequent, 1 - present. Items classified as abundant and frequent were found to be dominant (ARTIOLI et al. 2009). Subsequently, they were analyzed for temporal variation and between the sexes.

The maturation stages were defined macroscopically, classified as immature, maturing, mature and emptied, and subsequently analyzed for absolute and relative frequencies. The observed values of sex ratio (bimonthly and size classes) were compared with expected values (1:1) using the Chi-Square test $(\alpha=0.05)$. The reproductive period was established by analyzing the relative frequency of mature specimens for two-month periods, along with the maturation curve obtained from the bimonthly distribution of the mean values of the gonadosomatic index (GSI). The GSI is represented by the equation GSI = GW/ TW $x$ 100, where: GW is the gonad weight and TW is the total weight of the individual (VAzzoler 1996). The weight of the male gonad is made up by the inner part of the reproductive system, more specifically by the testes, bladder and gelatinous sperm duct; for females, only the ovaries are weighed (RENo et al. 2000).

For the estimation of fecundity, we selected gonads that were mature and had a high GSI (VAzzoler 1996). With the aid of a stereomicroscope, the oocytes were manually separated from the surrounding tissue and then counted. The absolute fecundity was defined as the number of oocytes to be released by the female when spawning. The relationship between TL and fecundity was analyzed using a simple linear regression (ZAR 1999).

\section{RESULTS}

We captured 135 individuals, including 82 females and 53 males. Over $90 \%$ of the individuals were collected in the 15 , 20 , and $25 \mathrm{~mm}$ mesh nets, primarily in the $15 \mathrm{~mm}$ mesh (50\%).
The number of individuals varied throughout the sampling period, being greater during the warmer months, from October through March (122), less in April and May (13), and equal to zero from June through September. In general, females were more abundant than males during the sampling period (Table I).

Table I. Sex ratio of Trachelyopterus lucenai specimens captured in Itapeva, Quadros and Malvas lagoons in the Tramandaí River system, Rio Grande do Sul. No individual was captured in July and August 2009.

\begin{tabular}{lcccc}
\hline \multicolumn{1}{c}{ Bimonths } & Females & Males & Total & $\mathrm{p}$ \\
\hline Nov-Dec/08 & 5 & 6 & 11 & 0.76 \\
Jan-Feb/09 & 10 & 6 & 16 & 0.32 \\
Mar-Apr/09 & 14 & 17 & 31 & 0.59 \\
May-Jun/09 & 3 & 0 & 3 & 0.08 \\
Jul-Aug/09 & - & - & - & - \\
Sep-Oct/09 & 2 & 0 & 2 & 0.16 \\
Nov-Dec/09* & 14 & 4 & 18 & 0.02 \\
Jan-Feb/10 & 18 & 9 & 27 & 0.08 \\
Mar-Apr/10 & 16 & 11 & 27 & 0.34 \\
\hline Total $^{*}$ & 82 & 53 & 135 & 0.01 \\
\hline
\end{tabular}

* Significant values $p<0.05$

The TL ranged from 106 to $226 \mathrm{~mm}($ mean $=164 \pm 17$ $\mathrm{mm}$ ) in females, and from 137 to $195 \mathrm{~mm}$ (mean $=169 \pm 13$ $\mathrm{mm}$ ) in males. The mean TL of females and males showed no significant differences ( $p>0.05$ ). When analyzed by size class, females were more abundant in the size classes of 120 and 150 $\mathrm{mm}$, and the males in the $180 \mathrm{~mm}$ class (Table II). We found a positive association between the weight and the total length of individuals, and both sexes showed allometric growth (females, $\mathrm{R}^{2}=0.85, \mathrm{p}<0.05, \mathrm{n}=82$; males, $\mathrm{R}^{2}=0.70, \mathrm{p}<0.05, \mathrm{n}$ =53) (Figs 2 and 3 ).

Table II. Sex ratio by size class of Trachelyopterus lucenai specimens captured in Itapeva, Quadros and Malvas lagoons in the Tramandaí River system, Rio Grande do Sul.

\begin{tabular}{ccccc}
\hline Size class & Females & Males & Total & $\mathrm{p}$ \\
\hline $120^{*}$ & 12 & 3 & 15 & 0.02 \\
$150^{*}$ & 59 & 31 & 90 & 0.00 \\
180 & 11 & 19 & 30 & 0.14 \\
\hline
\end{tabular}

* Significant values $p<0.05$.

We analyzed 135 stomachs; 13 were empty, and 122 had a fullness index of II or III. The intestinal quotient mean was $0.67 \pm 0.16$. The diet consisted of 26 items, grouped as: Nematoda, Mollusca, Annelida, other Arthropoda (Crustacea and Chelicerata, insects excluded), Insecta, Pisces, scales, and or- 

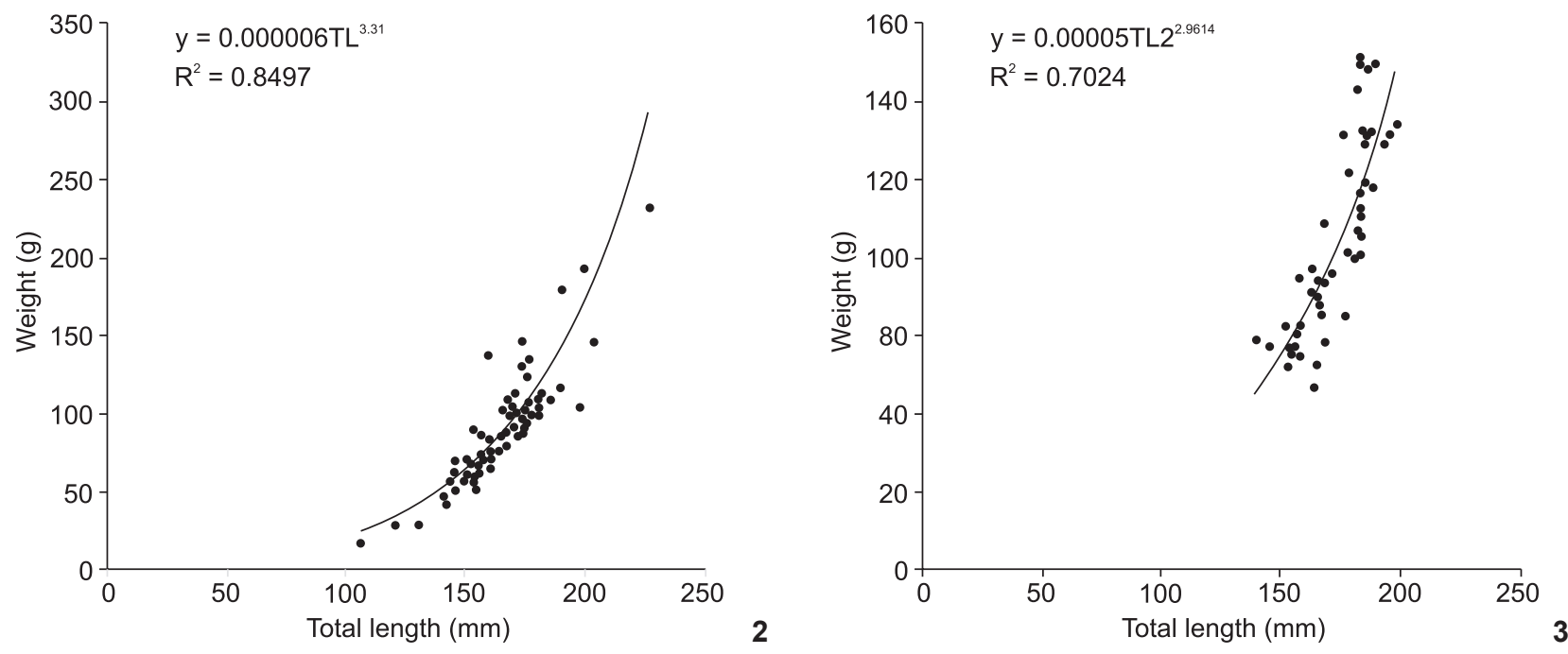

Figures 2-3. Length-weight relationships for females (2) and males (3) of Trachelyopterus lucenai captured in Itapeva, Quadros and Malvas lagoons in the Tramandaí River system, Rio Grande do Sul.

ganic matter. Overall, insects were consumed in greater quantities (61\%), followed by fish (19\%), and secondarily mollusks (10\%) and other Arthropoda (6\%). Other groups of organisms were present in fewer quantities and were classified as accidental. Fish scales and organic matter were present in all of the stomachs, and their amounts were not evaluated due to the difficulties involved in measuring them (Table III).

Temporally, fish intake increased in January and February $(\mathrm{PA}=36 \%, \mathrm{FO}=44 \%)$ and insect intake in March and April $(\mathrm{PA}=75 \%, \mathrm{FO}=43 \%)$. In May and June, mollusks and insects in particular $(\mathrm{PA}=57 \%, \mathrm{FO}=36 \%)$ were abundant and frequent $(\mathrm{PA}=57 \%, \mathrm{FO}=36 \%)$. In July and August, no individual was captured. In November and December, insects were the most abundant organisms, but fish were the most frequent (PA $=44 \%, \mathrm{FO}=23 \% ; \mathrm{PA}=30 \%, \mathrm{FO}=49 \%$, respectively) (Figs 4 and 5). The gastropod Pomacea spp., larvae of Ephemeroptera and Odonata, adults of Hemiptera and Coleoptera, and fish fragments were classified as dominants items. The diet did not differ between the sexes (Figs 6 and 7).

Of the total specimens caught, $70 \%$ were classified as mature (GSI female: $\min .=2.31$, mean $=6.96$, $\max .=15.02$; GSI males: $\min .=2.51$, mean $=9.04$, max. $=18.56)$, of which over $95 \%$ were captured from November through April. Immature and maturing individuals were prevalent in March and
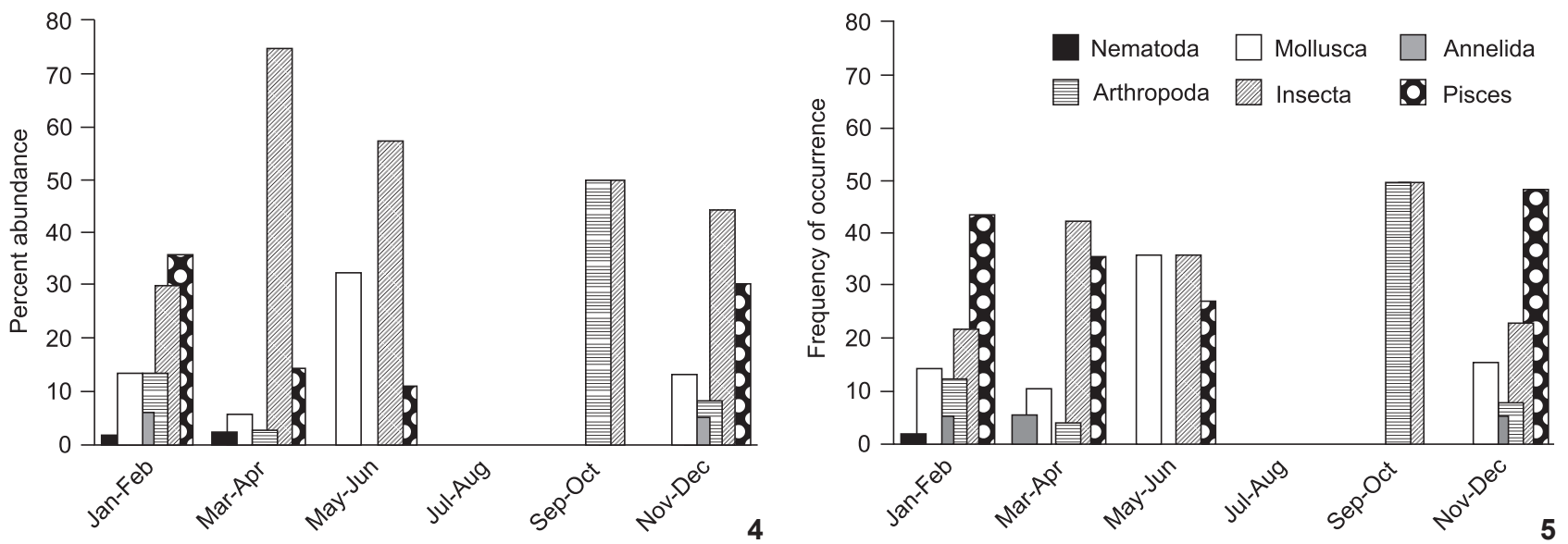

Figures 4-5. Bimonthly percentage values of abundance (4) and occurrence frequency (5) of food items found in stomachs of Trachelyopterus lucenai captured in Itapeva, Quadros and Malvas lagoons in the Tramandaí River system, Rio Grande do Sul. No individual was captured in July and August 2009. 
Table III. Percent abundance (PA), frequency of occurrence (FO) and relative importance (RI) of food items consumed by Trachelyopterus lucenai in Itapeva, Quadros and Malvas lagoons in the Tramandaí River system, Rio Grande do Sul. (1) present, (2) frequent, (3) abundant, (4) abundant and frequent, $\left({ }^{*}\right)$ fish scales and organic matter were present in all stomachs.

\begin{tabular}{|c|c|c|c|}
\hline Items & PA & $\mathrm{FO}$ & RI \\
\hline Nematoda & 1.41 & 4.10 & 1 \\
\hline \multicolumn{4}{|l|}{ Mollusca } \\
\hline \multicolumn{4}{|l|}{ Gastropoda } \\
\hline Pomacea & 6.21 & 16.39 & 4 \\
\hline Heleobia & 1.41 & 3.28 & 1 \\
\hline Bivalvia & 2.26 & 2.46 & 1 \\
\hline \multicolumn{4}{|l|}{ Annelida } \\
\hline Hirudinea & 2.82 & 4.92 & 1 \\
\hline \multicolumn{4}{|l|}{ Arthropoda } \\
\hline \multicolumn{4}{|l|}{ Chelicerata } \\
\hline Araneae & 0.28 & 0.82 & 1 \\
\hline \multicolumn{4}{|l|}{ Crustacea } \\
\hline Decapoda & 3.39 & 6.56 & 1 \\
\hline Isopoda & 1.13 & 3.28 & 1 \\
\hline Amphipoda & 0.56 & 1.64 & 1 \\
\hline Cladocera & 0.85 & 1.64 & 1 \\
\hline \multicolumn{4}{|l|}{ Insecta } \\
\hline Ephemeroptera (immature) & 9.89 & 10.66 & 4 \\
\hline Trichoptera (larvae) & 0.28 & 0.82 & 1 \\
\hline Odonata (nymph) & 5.08 & 13.11 & 4 \\
\hline Hemiptera (adults) & 5.65 & 14.75 & 4 \\
\hline Coleoptera (adults) & 38.42 & 28.69 & 4 \\
\hline Diptera (larvae) & 1.41 & 4.10 & 1 \\
\hline \multicolumn{4}{|l|}{ Pisces } \\
\hline Not identified & 14.69 & 42.62 & 4 \\
\hline \multicolumn{4}{|l|}{ Clupeiformes } \\
\hline Lycengraulis grossidens (Agassiz, 1829) & 0.56 & 1.64 & 1 \\
\hline \multicolumn{4}{|l|}{ Characiformes } \\
\hline Astyanax spp. & 1.69 & 4.92 & 1 \\
\hline Oligosarcus robustus Menezes, 1969 & 0.28 & 0.82 & 1 \\
\hline \multicolumn{4}{|l|}{ Siluriformes } \\
\hline Corydoras paleatus (Jenyns, 1842) & 0.28 & 0.82 & 1 \\
\hline Hisonotus leucofrenatus (Miranda Ribeiro, 1908) & 0.28 & 0.82 & 1 \\
\hline Pimelodella australis Eigenmann, 1917 & 0.28 & 0.82 & 1 \\
\hline Siluriformes not identified & 0.85 & 2.46 & 1 \\
\hline
\end{tabular}

*Fish scales and organic matter.

April (Table IV). The sex ratio was 1.5 females per male $\left(\chi^{2}=\right.$ $6.23, \mathrm{p}=0.01, \mathrm{df}=1, \mathrm{n}=135)$. Significant differences were also observed in November and December 2009 and in the 120 and $150 \mathrm{~mm}$ size classes (Tables I and II). The distribution of the relative frequency of mature males and females with the bimonthly mean values of GSI suggests a breeding season from October through March, with greatest activity in November and December (Figs 8-11). The mean fecundity was 1536 oo-
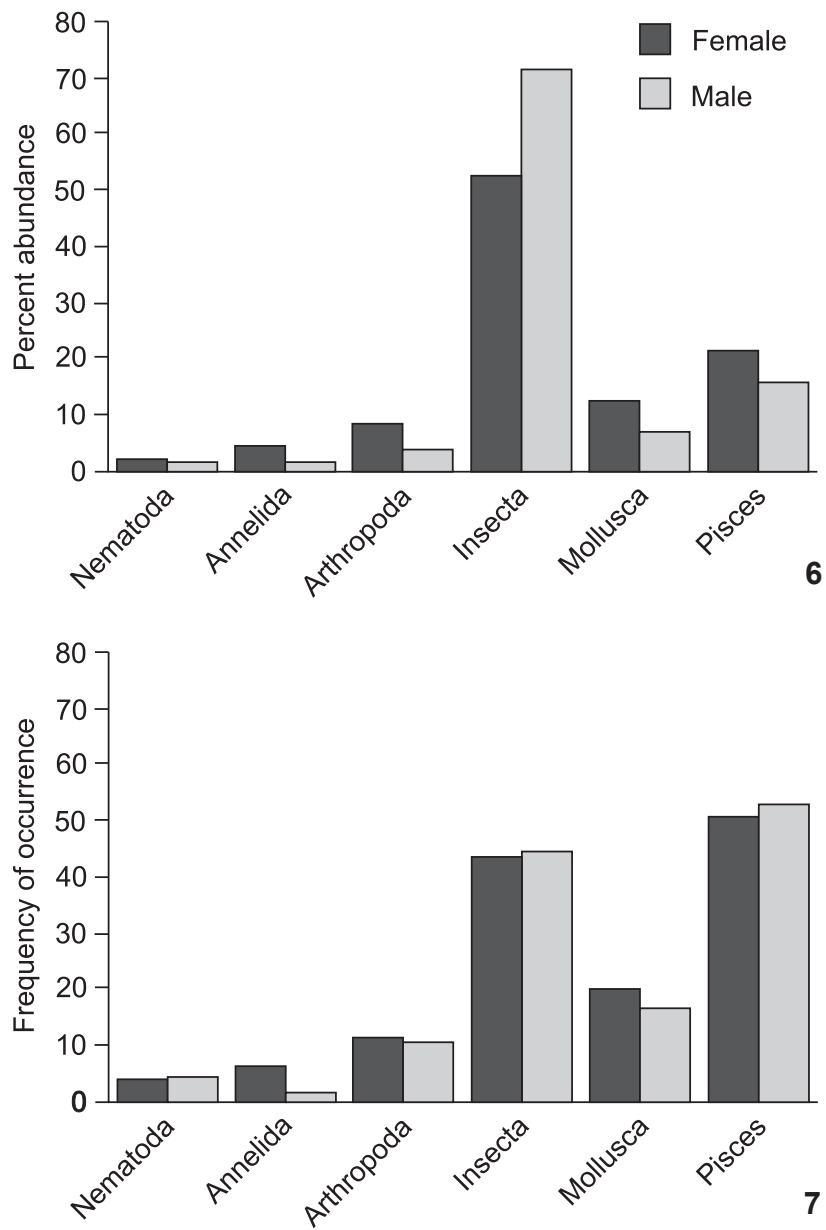

Figures 6-7. Variation between the sexes in the percentage values of abundance (6) and occurrence frequency (7) of food items found in the stomachs of Trachelyopterus lucenai captured in Itapeva, Quadros and Malvas lagoons in the Tramandaí River system, Rio Grande do Sul.

cytes per female (minimum $=910$, maximum $=2554$, number of mature females $=17$ ). We found a positive association between TL and fecundity (F 1.15 $=11.408, \mathrm{p}=0.004$ ) (Fig. 12). In general, highest water and air temperatures were coincident with peaks of rainfall (Fig. 13).

\section{DISCUSSION}

Gillnets are a passive sampling technique that are somewhat selective, mainly because of the behavior of the fish, and are appropriate for fish that swim actively in open water (HAYES 1989). In other aquatic systems, T. lucenai has been caught in meshes smaller than $35 \mathrm{~mm}$, between adjacent nodes (MilanI \& FonTOURA 2007). This may be due to the nocturnal movement of individuals in the water column in search of food (Moresco \& 

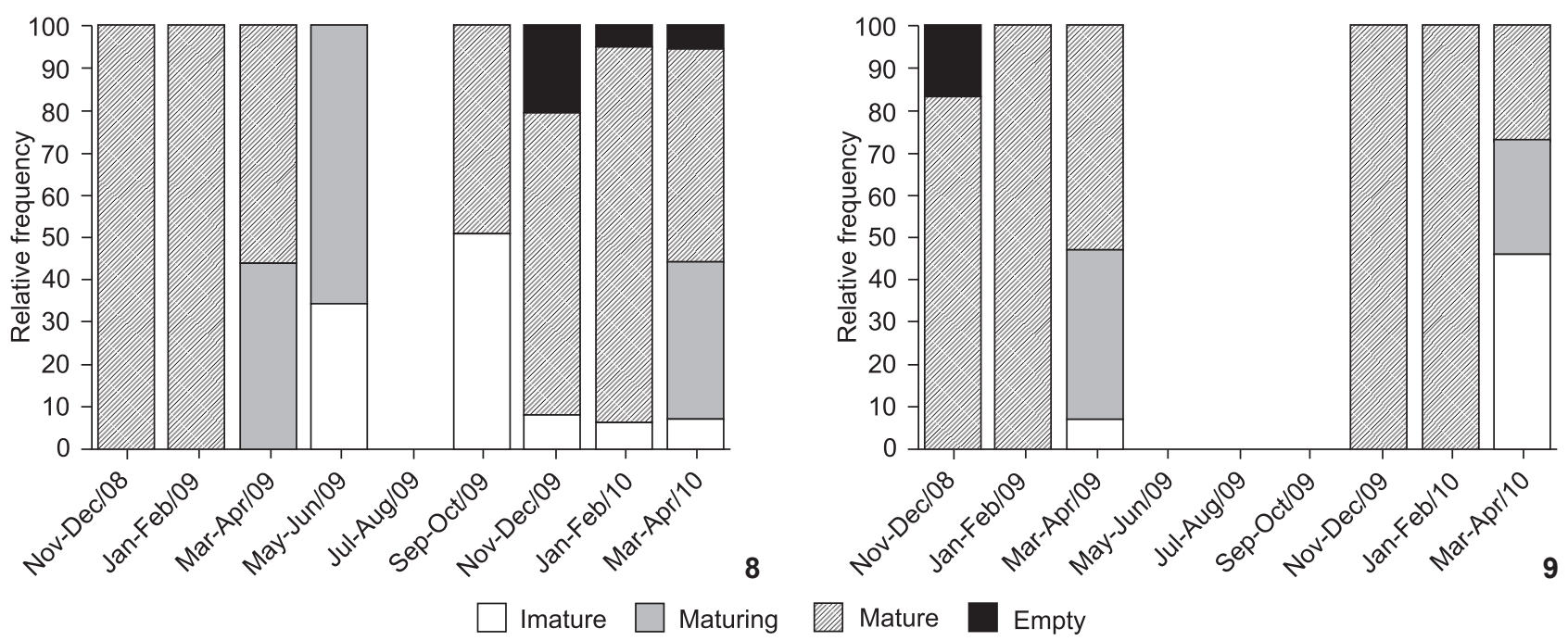

Figures 8-9. Relative frequency of different maturation stages of females (8) and males (9) of Trachelyopterus lucenai captured in Itapeva, Quadros and Malvas lagoons in the Tramandaí River system, Rio Grande do Sul. No individual was captured in July and August 2009.
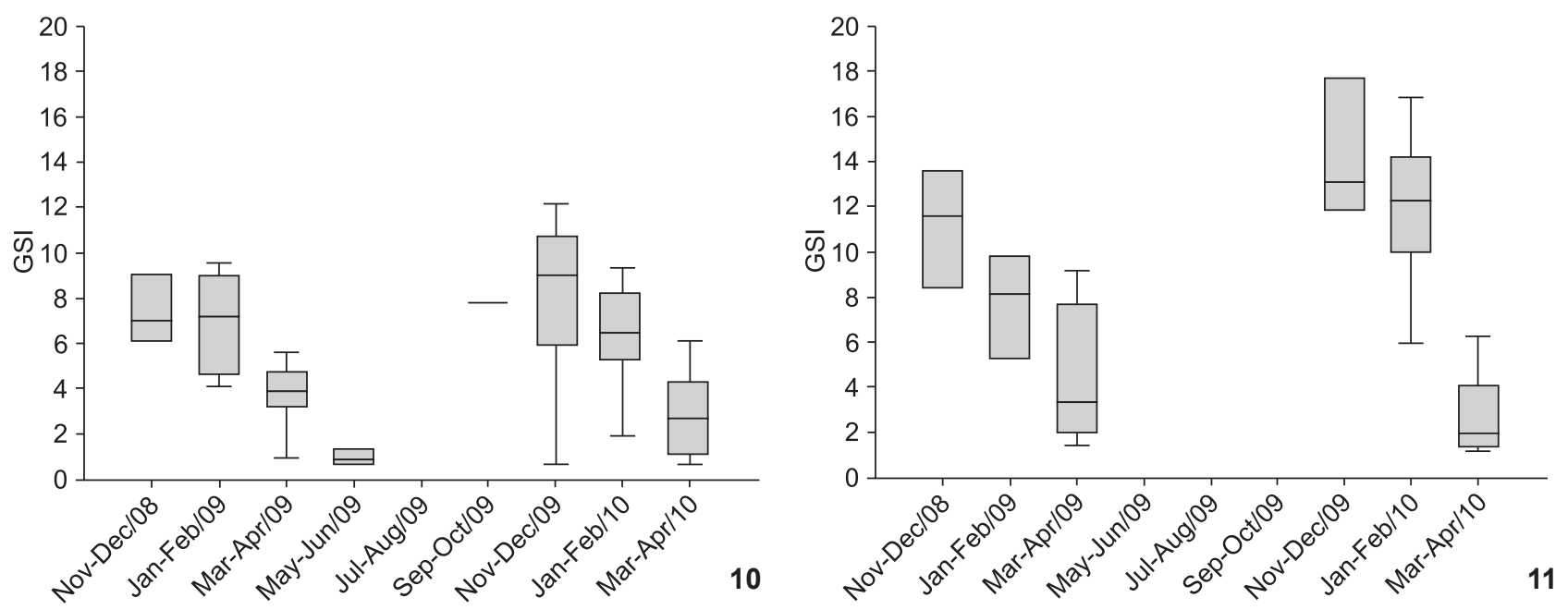

Figures 10-11. Mean values of the gonadosomatic index (GSI) for two-month periods, in females (10) and males (11) of Trachelyopterus lucenai captured in Itapeva, Quadros and Malvas lagoons in the Tramandaí River system, Rio Grande do Sul. No individual was captured in July and August 2009. Mean represented by horizontal bar and $25^{\text {th }}$ and $75^{\text {th }}$ percentiles as borders of box plots.

Bemvenuti 2005), or else, to the small size of auchenipterid species. We believe that our sampling design did not bias our results. More than ninety percent of the stomachs analyzed were full, or partially full, possibly because individuals of this species have nocturnal feeding habits and their digestion of insects is slow. The different temporal abundance of specimens in catches was similar to that observed for the Laguna dos Patos system, with the greatest catches in the warmer months (October to March) and smallest in the colder months (April to September). The decreases in fish availability in cooler periods may be re- lated to increased activity of natural predators such as the Lontra longicaudis Olfers, 1818 (Porciuncula \& Quintela 2010); a behavioral change caused by the reduced metabolism in cold weather (BeCKer 1998, Moresco \& Bemvenuti 2005); or seasonal differences in habitat occupation (BECKER 2001). In the case of the TRS, we suggest, without providing conclusive evidence, that the ricefield irrigation canals near the lagoons create favorable habitats for the temporal movement of species from these environments. There was no difference between the mean length of females and males, unlike what has been observed for Silurifor- 
Table IV. Absolute frequency (Af) and relative frequency (Rf) for two-month periods of Trachelyopterus lucenai individuals in different maturation stages, captured in the Itapeva, Quadros and Malvas lagoons in the Tramandaí River system, Rio Grande do Sul. No individual was captured in July and August 2009.

\begin{tabular}{|c|c|c|c|c|c|c|c|c|c|}
\hline \multirow{2}{*}{ Months } & \multicolumn{2}{|c|}{ Immature } & \multicolumn{2}{|c|}{ Maturing } & \multicolumn{2}{|c|}{ Mature } & \multicolumn{2}{|c|}{ Empty } & \multirow{2}{*}{ Total } \\
\hline & Af & $\mathrm{Rf}$ & Af & $\mathrm{Rf}$ & Af & Rf & Af & Rf & \\
\hline Nov-Dec/08 & 0 & 0 & 0 & 0 & 10 & 90.91 & 1 & 9.09 & 11 \\
\hline Jan-Feb/09 & 0 & 0 & 0 & 0 & 16 & 100.00 & 0 & 0 & 16 \\
\hline Mar-Apr/09 & 1 & 3.23 & 13 & 41.94 & 17 & 54.84 & 0 & 0 & 31 \\
\hline May-Jun/09 & 1 & 33.33 & 2 & 66.67 & 0 & 0 & 0 & 0 & 3 \\
\hline Jul-Aug/09 & - & - & - & - & - & - & - & - & - \\
\hline Sep-Oct/09 & 1 & 50.00 & 0 & 0 & 1 & 50.00 & 0 & 0 & 2 \\
\hline Nov-Dec/09 & 1 & 5.56 & 0 & 0 & 14 & 77.78 & 3 & 16.67 & 18 \\
\hline Jan-Feb/10 & 1 & 3.70 & 0 & 0 & 25 & 92.59 & 1 & 3.70 & 27 \\
\hline Mar-Apr/10 & 6 & 22.22 & 9 & 33.33 & 11 & 40.74 & 1 & 3.70 & 27 \\
\hline Total & 11 & 8.14 & 24 & 17.77 & 94 & 69.62 & 6 & 4.44 & 135 \\
\hline
\end{tabular}
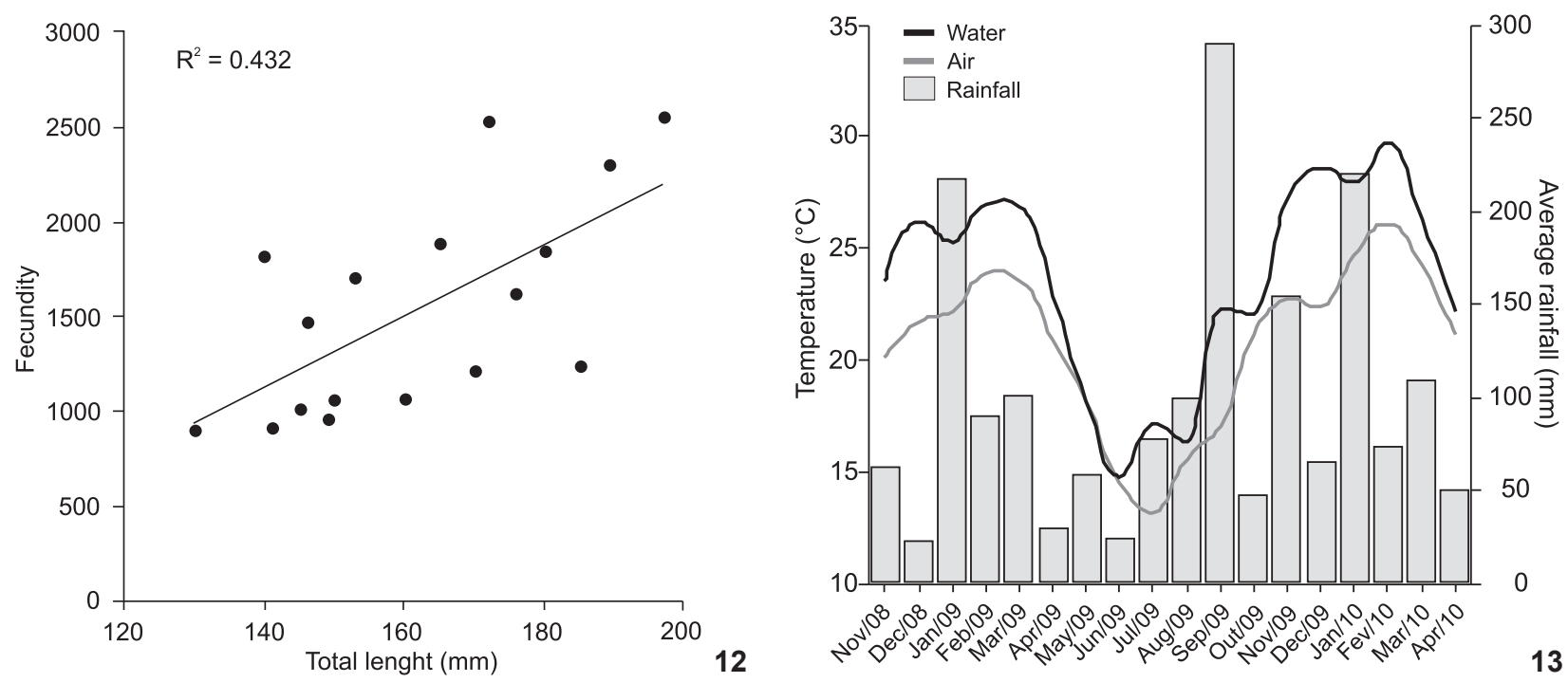

Figures 12-13. (12) Linear regression between fecundity and total length (mm) for 17 mature females of Trachelyopterus lucenai captured in Itapeva, Quadros and Malvas lagoons in the Tramandaí River system, Rio Grande do Sul. (13) Water temperature $\left({ }^{\circ} \mathrm{C}\right)$ per sample collection, and monthly means of air temperature $\left({ }^{\circ} \mathrm{C}\right)$ and rainfall $(\mathrm{mm})$ in the Municipality of Capão da Canoa, Rio Grande do Sul. Source: FEPAGRO, April 2010.

mes, a group in which females tend to be larger (AgostinHo \& Júlio 1999, Gomiero \& Braga 2007). However, males larger than females were observed in Trachelyopterus galeatus (Linnaeus, 1766) (= Trachychorystes galeatus) in the Banabuiú Reservoir, Ceará (Nomura et al. 1976), indicating that the general pattern described for Siluriformes does not include the Auchenipteridae. The allometric growth shown by both sexes differed from the pattern recorded for the Guaíba Lake (BECKER 2001). This discrepancy may be a function of the recent establishment of this species in the TRS, the differences in the way females and males use energy resources, or simply a result of sampling artifacts.

With regards to feeding, the low intestinal quotients observed for T. lucenai are typical of carnivores (BARBIERI et al. 1994). However, the calculation of the intestinal quotient, commonly used to characterize the diet of fish, is insufficient to express the degree of feeding specialization (ANGELESCU \& GNERI 1949). Although the species consumed basically items of animal origin, these were predominantly insects and fish. High rates of consumption of these categories were also observed at the Guaíba Lake (BECKER 1998) and ponds of the Estação 
Ecológica do Taim, which indicates that T. lucenai should be classified as a secondary consumer (Moresco \& BeMvenuti 2005, GARCIA et al. 2006a). According to a study conducted in the Caconde Lagoon (Rodrigues \& Hartz 2001), most native species feed on items from the substrate, such as insect larvae, algae and detritus. Therefore, T. lucenai would not be competing directly for food with the local fish fauna. However, because this lagoon is isolated from the rest of the TRS and has a muddy bottom, the food items that were found in the stomachs of our subjects differ in relative quantity and in quality from the items generally consumed in other lakes of the TRS.

The large amounts of insects consumed suggest a relationship with fluctuations in temperature and rainfall, as temperature increases associated with heavy rainfall events lead to increases in the densities of macrobenthos and insects in general, due to high water levels and consequent flooding of the banks (CEnZANo \& WÜrdig 2006). The ingestion of animals that live in microhabitats from the bottom to the water surface indicates that $T$. lucenai exploits the entire water column in search for food, as previously observed for the species (BECKER 1998) and its congeners T. striatulus (Steindachner, 1877) in the Lajes Reservoir, Rio de Janeiro (DiAs et al. 2005, Dos SANTos et al. 2009) and T. galeatus (Linnaeus, 1766) (= Parauchenipterus galeatus) in Itaipu Reservoir, Paraná (ANDRIAN et al. 1994).

In the Laguna dos Patos system, T. lucenai ingested especially autochthonous items (fish, crustaceans, insect larvae and snails). The allochthonous material ingested was less important, and included flowers, seeds, roots and terrestrial insects. Due to the consumption of different food resources, the species was classified as opportunistic-generalist, having a wide feeding flexibility (BeCKer 1998, Moresco \& BemVenuti 2005). We believe that the species' food, in our data, is primarily composed of autochthonous items, because the lagoons under study do not have a riparian vegetation that can provide allochthonous material for fish food. Thus, the variety of autochthonous food groups consumed suggests that the species has an opportunistic-generalist food habit in the TRS. However, studies correlating the abundance of items in the environment with their rates of consumption by species, illustrate, in concrete terms, the opportunistic habit reported for the species in aquatic systems in Rio Grande do Sul. The similarity in diet between females and males indicates that there is no spatial segregation, confirming the results found by BECKER (1998).

Females predominated during the sampling period, similarly to what had been described for the Guaiba Lake (BECKER 2001). This ratio is significantly different from $1: 1$, and may be due to differences in the size of females and males (HarTz \& BARBIERI 1994), or related to the amount of available food, which under optimal conditions, would lead to a higher frequency of females in the population (NIKOLSKII 1969, GuRgel 2004). The sex ratio of this species, with internal fertilization, and morphologic pattern of males with the presence of strong bony hooks on the dorsal and pectorals fins suggest that males com- pete for mature females as described for Hoplosternum littorale Hancock, 1828 (Callichthyidae) in the swamps of Venezuela (Winemiller 1987). However, studies should be conducted to test this hypothesis.

The reproductive period in the Laguna dos Patos system occurs from November through February, with the male gonadal development peaking before that of females (BECKER 2001, Milani \& Fontoura 2007, Marques et al. 2007). In this study, the reproductive period was longer (from October through March) and no differences in the development peaks of female and male gonad was evident. The reproductive period coincided with the months when more specimens were caught, indicating the period of greatest activity. Abiotic factors such as temperature, photoperiod and rainfall directly influence the reproductive period of fish (VAzzoler 1996). For auchenipterids such as $T$. galeatus that inhabit regions with well-defined rainy and dry periods, the breeding season coincides with periods of heavy rainfall, resulting in high water levels (VAzzoler et al. 1997, Medeiros et al. 2003). However, in the Laguna dos Patos and Tramandaí River systems, in a subtropical climate (SEeliger et al. 1997, Ferraro \& Hasenack 2009), there is not a clearly defined rainy season, and therefore we assume that temperature variations are the main environmental factor initiating the reproductive period of T. lucenai.

This is the first estimate of fecundity for the species. The low values agree with the pattern described for Siluriformes (Araújo \& Garutti 2002, Duarte \& Araújo 2002, Sá-Oliveira \& Chellappa 2002) and may be related to the insemination mechanism. High values of fecundity are characteristic of species that have free eggs and little or no parental care (WINEMILLER 1989). Although parental care is not known in T. lucenai, these values were similar to those described for species of Loricariidae such as Loricariichthys anus (Valenciennes, 1835) and Hypostomus affinis (Steindachner, 1877) that showed 466 to 1784 oocytes per spawning (Bruschi Jr. et al. 1997, Mazzoni \& Caramaschi 1997). The positive correlation between female fecundity and length follows the pattern described by VAzzoLER (1996). In other words, the longer the female, more oocytes are released at the time of spawning.

The results of this study demonstrated that the species showed few differences from the feeding and reproduction patterns described for their source systems. The feeding behavior remained generalist-opportunist, but the food was based on autochthonous items, and insects and fish were the items most consumed. If on one hand the species did not compete directly with insectivores or piscivores, on the other hand, the fact of being a generalist with broad feeding plasticity facilitates its establishment in new environments. The reproductive period was long, in spite of the low fecundity. In order to better understand the reproductive strategy of this species, we suggest that more studies on some aspects of its reproduction, such as size at first maturity and type of spawning are carried out. We were not able to evaluate those parameters because of 
the small size of our samples. The abundance of females, along with the insemination mechanism, could indicate a possible competitive behavior among males. Studies in other regions have shown how the establishment of invasive species may be associated with deleterious effects on the native fauna (MoyLE \& Light 1996, Simberloff 2005). We emphasize the need for monitoring programs and assessment of allochthonous species, in order to minimize their negative impacts on aquatic ecosystems of the coastal plain of southern Brazil.

\section{ACKNOWLEDGEMENTS}

We thank the Centro de Estudos Costeiros Limnológicos e Marinhos (CECLIMAR) and the Ministério da Agricultura e Pesca for logistical and financial support; Pedro C. Neto, Osvaldo Machado and Manuel Nunes for their invaluable assistance with fieldwork; Fernando Becker and Clarice Fialho for criticisms and suggestions; Janet Reid and Tiago Carvalho for English review; the Instituto Brasileiro do Meio Ambiente e dos Recursos Naturais Renováveis, which granted the sampling license (\# 18439-1). S.M.H. acknowledges CNPq for a productivity grant (306816/2010-5) and L.G.S.A. is grateful for a CAPES doctoral fellowship.

\section{LITERATURE CITED}

Agostinho, A.A. \& H.F. Júlio. 1999. Peixes da bacia do alto rio Paraná, p. 374-400. In: R.H. Lowe-McConnell (Ed.). Estudos ecológicos de comunidades de peixes tropicais. São Paulo, EDUSP, 534p.

Agostinho, A.A.; F.M. Pelicice \& H.F. Júlio Jr. 2005. Introdução de espécies em águas continentais brasileiras: uma síntese, p. 13-23. In: O. Rocha; E.L.G. Espíndola; N. Fenerich-Verani; J.R. Verani \& A.C. Rietzler (Eds). Espécies invasoras em águas doces - estudo de caso e propostas de manejo. São Carlos, Universidade Federal de São Carlos, 416p.

Andrian, I.F.; G. Barbieri \& H.F. Júlio JR. 1994. Distribuição temporal e espacial de Parauchenipterus galeatus Linnaeus 1766, (Siluriformes, Auchenipteridae) nos primeiros anos após a formação do reservatório de Itaipu, PR. Revista Brasileira de Biologia 54 (3): 469-475.

Angelescu, V. \& F. Gneri. 1949. Adaptaciones del aparato digestivo al regimens alimenticios en algunos peces del Rio Uruguay y del Rio de La Plata. Tipo omnívoro y iliofago en representantes de las familias Loricariidae y Anastomidae. Revista del Museo Argentino de Ciencias Naturales Bernardino Rivadavia 1: 162-272.

Araújo, F.G.; S. Duarte; R.S. Goldberg \& I. Fichberg. 2000. Ciclo reprodutivo de Parauchenipterus striatulus (Pisces-Auchenipteridae) na represa de Ribeirão das Lajes - RJ. Arquivo Brasileiro de Medicina Veterinária e Zootecnia 52 (3): 276-284.

Araújo, R.B. \& V. Garutti. 2002. Biologia Reprodutiva de Aspidoras fuscoguttatus (Siluriformes, Callichthyidae) em ri- acho de cabeceira da bacia do alto rio Paraná. Iheringia, Série Zoologia 92 (4): 89-98.

Artioli, L.G.S. \& R. Maia. 2010. Pisces, Siluriformes, Auchenipteridae, Trachelyopterus lucenai Bertoletti, Pezzi da Silva \& Pereira, 1995: historical ocurrence and distributions extension. Check List 6 (4): 515-516.

Artioli, L.G.S.; J.P. Vieira; A.M. Garcia \& M.A. Bemvenuti. 2009. Distribuição, dominância e estrutura de tamanhos da assembleia de peixes da lagoa Mangueira, sul do Brasil. Iheringia, Série Zoologia 99 (4): 409-418.

Barbieri, G.; A.C. Peret \& J.R. Verani. 1994. Notas sobre a adaptação do trato digestivo ao regime alimentar em espécies de peixes da região de São Carlos (SP). I. Quociente Intestinal. Revista Brasileira de Biologia 54 (1): 63-69.

BeCKer, F.G. 1998. Feeding habits of Trachelyopterus lucenai (Pisces, Auchenipteridae) in lake Guaíba, RS, Brazil. Biociências 6 (1): 89-98.

BECKER, F.G. 2001. Observations on the reproduction, sex ratio and size composition of Trachelyopterus lucenai (Teleostei, Auchenipteridae) in lake Guaíba, RS, Brazil. Biociências 9 (2): 85-96.

Becker, F.G.; K.M. Grosser; P.C. Milani \& A.S. Braun. 2007. Peixes, p. 262-275. In: F.G. Becker; L.A. Moura \& R.A. Ramos (Eds). Biodiversidade. Regiões da Lagoa do Casamento e dos Butiazais de Tapes, Planície Costeira do Rio Grande do Sul. Brasília, Ministério do Meio Ambiente, 388p.

Bertoletti, J.J.; J.F. Pezzi da Silva \& E.H.L. Pereira. 1992. Nota sobre o gênero Trachelyopterus Valenciennes, 1840, no estado do Rio Grande do Sul, Brasil (Siluriformes, Auchenipteridae). Comunicações do Museu Ciências da PUCRS Série Zoologia 5 (10): 169-177.

Bruschi Jr, W.; A.C. Peret; J.R. Verani \& C.B. Fialho. 1997. Reprodução de Loricariichthys anus (Valenciennes, 1840) da lagoa Emboaba, Osório, RS, Brasil. Revista Brasileira de Biologia 57 (4): 677-685.

Burns, J.R.; A.D. Meisner; S.H. Weitzman \& L.R. Malabarba. 2002. Sperm and spermatozeugma ultrastructure in the inseminating catfish, Trachelyopterus lucenai (Ostariophysi: Siluriformes: Auchenipteridae). Copeia 1: 173-179.

Cenzano, C.S.S. \& N.L. WÜrdig. 2006. Spatial and temporal variations of the benthic macrofauna in different habitats of a lagoon of the northern coastal system of Rio Grande do Sul State, Brazil. Acta Limnologica Brasiliensia 18 (2): 153-163. DE PINNA, M.C.C. 1998. Phylogenetic relationships of Neotropical Siluriformes (Teleostei: Ostariophysi): historical overview and synthesis of hypotheses, p.279-330. In: L.R. Malabarba; R.E. Reis; R.P. Vari; Z.M.S. Lucena \& C.A.S. Lucena (Eds). Phylogeny and classification of Neotropical fishes. Porto Alegre, Museu de Ciências e Tecnologia PUCRS, 603p.

Dias, A.C.M.I.; C.W.C. BRAnCo \& V.G. Lopes. 2005. Estudo natural da dieta de peixes no reservatório do Ribeirão das Lajes, Rio de Janeiro, Brasil. Acta Scientiarum Biological Sciences 27 (4): 355-364. 
dos Santos, A.F.G.N.; F. Racca-Filho; S.N. dos Santos \& F.G. AraÚJo. 2009. The fish Trachelyopterus striatulus (Siluriformes: Auchenipteridae) used to sample insects in a tropical reservoir. Revista de Biologia Tropical 57 (4): 1081-1091.

Duarte, S. \& F.G. Araújo. 2002. Fecundity of the Hypostomus affinis (Siluriformes, Loricariidae) in the Lajes Reservoir, Rio de Janeiro, Brazil. Revista de Biologia Tropical 50 (1): 193-197.

Espínola, L.A. \& H.F. Júlio JR. 2007. Espécies invasoras: Conceitos, Modelos e Atributos. Interciência 32 (9): 580-585.

Ferraris JR, C.J. 2007. Checklist of catfishes, recent and fossil (Osteichthyes: Siluriformes), and catalogue of siluriform primary types. Zootaxa 1418: 1-628.

Ferraro, L.W. \& H. Hasenack. 2009. Clima, p. 26-31. In: N.L. Würdig \& S.M.F. DE FreItas (Orgs). Ecossistemas e Biodiversidade do litoral norte do RS. Porto Alegre, Editora Nova Prova, 287p.

Garcia, A.M.; D. Hoeinghaus; J.P. Vieira; K. Winemiller; D.M.L. Motta Marques \& M. Bemvenuti. 2006a. A Preliminary examination of food web structure of Nicola Lake (Taim Hydrological System, south Brazil) using dual C and N stable isotope analyses. Neotropical Icththyology 4 (2): 279-284.

Garcia, A.M.; J.P. Vieira; M.A. Bemvenuti; D.M.L. Motta Marques; M. BuRns; A. MORESCO \& V. CONDINI. 2006b. Checklist comparison and dominance patterns of the fauna at Taim Wetland, South Brazil. Neotropical Icththyology 4 (2): 261-268.

Gomiero, L.M. \& F.M.S. Braga. 2007. Reproduction of a fish assemblage in the state of São Paulo, southeastern Brazil. Brazilian Journal of Biology 67 (2): 283-292.

Gurgel, H. De C.B. 2004. Estrutura Populacional e época de reprodução de Astyanax fasciatus (Cuvier) (Characidae, Tetragonopterinae) do Rio Ceará Mirim, Poço Branco, Rio Grande do Norte, Brasil. Revista Brasileira de Zoologia 21 (1): 131-135.

Hartz, S.M. \& G. Barbieri. 1994. Dinâmica da reprodução de Cyphocharax voga (Hensel 1869) da lagoa Emboaba, RS, Brasil (Characiformes, Curimatidae). Revista Brasileira de Biologia 54 (3): 459-468.

Hasenack, H. \& L. Ferraro. 1989. Considerações sobre o clima da região de Tramandaí, RS. Pesquisas 22: 53-70.

HaYes, J.W. 1989. Comparison between a fine mesh trap net and five other fishing gears for sampling shallow-lake fish communities in New Zealand. Journal of Marine and Freshwater Research 23: 321-324.

HysLop, E.J. 1980. Stomach content analysis - a review of methods and their application. Journal of Fish Biology 17: 411-429.

Marques, C.S.; A.S. Braun \& N.F. Fontoura. 2007. Estimativa de tamanho de primeira maturação a partir de dados de IGS: Oligosarcus jenynsii, Oligosarcus robustus, Hoplias malabaricus, Cyphocharax voga, Astyanax fasciatus (Characiformes), Parapimelodus nigribarbis, Pimelodus maculatus, Trachelyopterus lucenai, Hoplosternum littorale, Loricariichthys anus (Siluriformes) e Pachyurus bonariensis (Perciformes) no lago Guaíba e Laguna dos Patos, RS. Biociências 15 (2): 230-256.
Mazzoni, R. \& E.P. CARAMASCHI. 1997. Spawning season, ovarian development and fecundity of Hypostomus affinis (Osteichthyes, Loricariidae). Revista Brasileira de Biologia 57 (3): 455-462.

MCCAFFERTY, W.P. 1981. Aquatic entomology: the fishermen's and ecologist's illustred guide to insects and their relatives. Boston, Jones and Barlett, $\mathrm{XV}+448 \mathrm{p}$.

Medeiros, A.P.T.; N.T. Chellappa \& S. Chellappa. 2003. Aspectos reprodutivos do cangati, Parauchenipterus galeatus Linnaeus (Osteichthyes, Auchenipteridae) da Lagoa Extremoz, Rio Grande do Norte, Brasil. Revista Brasileira de Zoologia 20 (4): 647-650.

Meisner, A.D.; J.R. Burns; S.H. Weitzman \& L.R. Malabarba. 2000. Morphology and histology of the male reproductive system in two species of inseminating South American catfishes, Trachelyopteurs lucenai and T. galeatus (Teleostei: Auchenipteridae). Journal of Morphology 246: 131-141.

Milani, P.C.C. \& N.F. Fontoura. 2007. Diagnóstico da pesca artesanal na lagoa do casamento, sistema nordeste da Laguna dos Patos: uma proposta de manejo. Biociências 15 (1): 82-125.

Moresco, A. \& M.A. Bemvenuti. 2005. Morphologic features and feeding analysis of the black catfish Trachelyopterus lucenai Bertoletti, Pezzi da Silva \& Pereira, 1995 (Siluriformes, Auchenipteridae). Acta Limnologica Brasiliensia 17 (1): 37-44.

Moyle, P.B. \& T. Light. 1996. Biological invasions of fresh water: empirical rules and assembly theory. Biological Conservation 78: 149-161

Mugnai, R.; J.L. Nessimian \& D.F Baptista. 2010. Manual de identificação de macroinvertebrados aquáticos do Estado do Rio de Janeiro. Rio de Janeiro, Technical Books, 174p.

NikolskiI, G.V. 1969. Theory of fish population dynamics. Edinburgh, Oliver and Boyd, 352p.

Nomura, H.; J.O. Chacon; L. Nemoto \& I.M. Mattos. 1976. Idade e crescimento do cangati, Trachycorystes galeatus (Linnaeus, 1766) (Osteichthyes, Nematognathi, Auchenipteridae) do açude Banabuiú (Quixadá, Ceará, Brasil). Revista Brasileira de Biologia 36 (2): 521-525.

Porciuncula, R.A. \& F.M. Quintela. 2010. A record of invasive black catfish (Trachelyopterus lucenai) predation by the neotropical river otter (Lontra longicaudis) in restinga of Rio Grande, southern Brazil. IUCN Bulletin 27 (1): 50-53.

Reno, P.L.; M.A. McCollum; C.O. Lovejoy \& R.S. Meindl. 2000. Morphology and histology of the male reproductive system in two species of internally inseminating south american catfishes, Trachelyopterus lucenai e T. galeatus. Journal of Morphology 246 (2): 131-141.

Rodrigues, G. \& S.M. Hartz. 2001. Food dynamics of fish and the interaction with macroinvertebrates from a shallow lake in Southern Brazil. Proceedings of the International Association of Theoretical and Applied Limnology 27: 3309-3314. 
Saccol-Pereira, A. \& C.B. Fialho. 2010. Seasonal and diel variation in the fish assemblage of a Neotropical delta in southern Brazil. Iheringia, Série Zoologia 100 (2): 169-178.

SÁ-Oliveira, J.C. \& S. Chellappa. 2002. Fecundidade e tipo de desova do tamuatá, Hoplosternum littorale Hancock (Osteichthyes, Siluriformes) no Rio Curiaú, Macapá, Amapá. Revista Brasileira de Zoologia 19 (4): 1053-1056.

SCHÄFER, A. 1988. Tipificação ecológica das lagoas costeiras do Rio Grande do Sul, Brasil. Acta Limnologica Brasiliensia 2: 29-55.

Schifino, L.C.; C.B. Fialho \& J.R. Verani. 2004. Fish community composition, seasonality and abundance in Fortaleza lagoon, Cidreira. Brazilian Archives of Biology and Technology 47 (5): 755-763.

Schwarzbold, A. \& A. SchäFer. 1984. Gênese e morfologia das lagoas costeiras do Rio Grande do Sul - Brasil. Amazoniana 9 (1): 87-104.

Seeliger, U.; C. Odebrecht \& J.P. Castello. 1997. Subtropical convergence environments: The coast and sea in the southwestern Atlantic. Berlin, Springer-Verlag, 308p.
SimberLoff, D. 2005. Non-native species do threaten the natural environment! Journal of Agricultural and Environmental Ethics 18: 595-607.

VAzzoler, A.E.A.M. 1996. Biologia da Reprodução de Peixes Teleósteos: Teoria e Prática. Maringá, EDUEM, 169p.

Vazzoler, A.E.A.M.; A.A. Agostinho \& N.S. Hahn. 1997. A planície de inundação do alto rio Paraná. Maringá, EDUEM, 460p.

WinemiLler, K.O. 1987. Feeding and reproductive biology of the currito, Hoplosternum littorale, in the Venezuelan llanos with comments on the possible function of the enlarged male pectoral spines. Environmental Biology of Fishes 20 (3): 219-227.

Winemiller, K.O. 1989. Patterns of variation in life history among South American fishes in seasonal environments. Oecologia 81: 225-241.

ZAR, J.H. 1999. Biostatistical Analysis. New Jersey, Prentice Hall Press, 663p.

ZAVALA-CAMIM, L.A. 1996. Introdução aos estudos sobre alimentação natural em peixes. Maringá, EDUEM, 129p.

Submitted: 28.VI.2012; Accepted: 13.II.2013.

Editorial responsibility: Vinicius Abilhoa 